\title{
The Covid-19 economic crisis: dangerously unique
}

\author{
Claudio Borio ${ }^{1}$
}

Published online: 24 September 2020

(c) National Association for Business Economics 2020

\begin{abstract}
The Covid-19 crisis is unique in several respects. This devastating recession does not have an economic origin, will dance largely to the tune of non-economic factors, and is truly global. The policy response has been equally unique, in terms of speed, size and scope, eliciting an unprecedented concerted effort combining monetary, fiscal and prudential policies. This has contained the fallout. At the time of writing, financial markets have rebounded to the point of looking exuberant, but it all feels more like a truce than a peace treaty. The crisis is transitioning from the liquidity to the solvency phase in a context of limited and shrinking room for policy manoeuvre. All this raises difficult near- and longer-term challenges. Rebuilding policy buffers in all policy areas is likely to be the policy challenge of the decade ahead.
\end{abstract}

Keywords COVID-19 $\cdot$ Macroeconomic policies $\cdot$ Illiquidity $\cdot$ Insolvency $\cdot$ Debt $\cdot$ Inflation

Thank you for the invitation to speak at this event; I am glad to be back.

In the next 20 minutes or so, I would like to reflect on the current economic crisis, the response so far and the challenges ahead. In doing so, I will draw heavily on the BIS Annual Economic Report (2020); I strongly encourage you to read it!

My takeaways? I would say three. First, a unique crisis has called for a unique response. Second, things are looking up, but it feels more like a truce than a peace treaty. In fact, the crisis is transitioning from the liquidity to the solvency phase. Finally, depending on how things evolve, there could be serious challenges ahead. Some of these challenges are old, and some are new, or at least old ones in a different guise. If there is a long-term challenge that I would highlight, it is the need to rebuild policy buffers. Monetary, fiscal and prudential policy buffers should be rebuilt as soon as conditions allow.

Let me take each point in turn: the policy response, the near-term challenges, and the longer-term ones.

Presentation made at the NABE Perspectives on the Pandemic Webinar Series, July 2, 2020.

\section{Claudio Borio}

Bank for International Settlements, Basel, Switzerland

\section{A unique crisis, a unique policy response}

Much has rightly been said about the uniqueness of this crisis. The crisis has resulted from a policy to tackle a health emergency through containment measures. Hence characterisations such as "putting the global economy into an induced coma" or "into hibernation". And it has induced contractions in output and employment that have been even steeper than those during the Great Depression. Hence characterisations such as "a global sudden stop" (Fig. 1).

All this means that, in contrast to the Great Financial Crisis (GFC) of 2007-2009, the present crisis has three key features. It is truly exogenous, not the result of the unravelling of previous financial imbalances - the typical recession trigger since the mid-1980s. It is truly uncertain, in the specific sense that the wide range of possibilities depends on unpredictable non-economic factors. And it is truly global: despite how the 2007-2009 crisis is generally portrayed, many countries did not actually experience it, not least in Asia.

A unique crisis calls for a unique response. The response has been unique in terms of objectives: not so much to boost aggregate demand so as to elicit increases in supply-home confinement has made the two highly unresponsive to traditional macroeconomic stimulus - but to offer a lifeline to firms and households during lockdowns, by providing the necessary bridge financing and resources. It has been unique in terms of scope: there has been unprecedented 


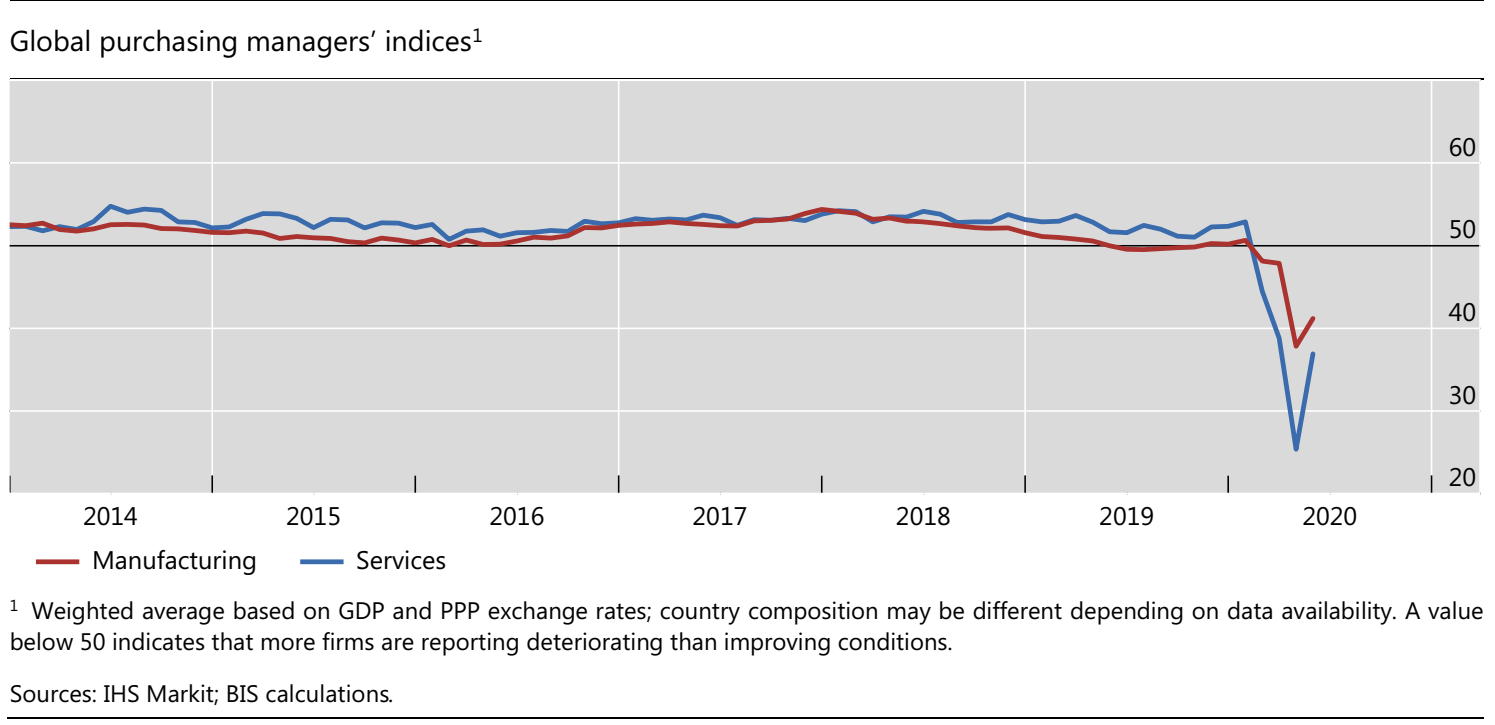

Fig. 1 A global sudden stop

coordination between monetary, fiscal and prudential policies. And it has been unique in terms of the characteristics of the response in each of the policy areas.

Take monetary, prudential and fiscal policy in turn.

Monetary policy has relied less on interest rate cuts than on its time-honoured lender of last resort function. To be sure, cuts have been implemented; but more to instil confidence than to boost demand through the usual channels. For its part, the lender of last resort function has hardly followed standard script, as it has been adapted to the nature of the shock and the evolving structure of the financial system.

This adaptation deserves particular attention.

In one respect, speed and scope aside (Table 1), the adaptation has simply extended the evolution already seen during the GFC because of the rapid growth of market-based finance relative to bank finance (Fig. 2). Central banks have acted more as dealers or, strictly speaking, buyers of last resort than just lenders of last resort. Hence, their large-scale purchases of both private and public sector securities in an

Table 1 Central banks' unprecedented response Source National data

\begin{tabular}{|c|c|c|c|c|c|c|c|c|c|c|c|c|c|c|c|c|}
\hline \multirow[t]{2}{*}{ Type of tool } & \multirow[t]{2}{*}{ Measures } & \multicolumn{7}{|c|}{ Advanced economies } & \multicolumn{8}{|c|}{ Emerging market economies } \\
\hline & & US & EA & JP & GB & $\mathrm{CA}$ & $\mathrm{AU}$ & $\mathrm{CH}$ & $\mathrm{BR}$ & $\mathrm{CN}$ & ID & IN & KR & MX & $\mathrm{TH}$ & $\mathrm{ZA}$ \\
\hline Interest rate & Policy rate cut & $\checkmark$ & & & $\checkmark$ & $\checkmark$ & $\checkmark$ & & $\checkmark$ & $\checkmark$ & $\checkmark$ & $\checkmark$ & $\checkmark$ & $\checkmark$ & $\checkmark$ & $\checkmark$ \\
\hline \multirow[t]{2}{*}{ Lending/liquidity } & Gen. liquidity provision ${ }^{\mathrm{a}}$ & $\checkmark$ & $\checkmark$ & $\checkmark$ & $\checkmark$ & $\checkmark$ & $\checkmark$ & & $\checkmark$ & $\checkmark$ & $\checkmark$ & $\checkmark$ & $\checkmark$ & $\checkmark$ & $\checkmark$ & $\checkmark$ \\
\hline & Specialised lending & $\checkmark$ & $\checkmark$ & $\checkmark$ & $\checkmark$ & & $\checkmark$ & $\checkmark$ & $\checkmark$ & $\checkmark$ & & $\checkmark$ & $\checkmark$ & $\checkmark$ & $\checkmark$ & \\
\hline \multirow{4}{*}{ Asset purchases/sales } & Government bonds & $\checkmark$ & $\checkmark$ & $\checkmark$ & $\checkmark$ & $\checkmark$ & $\checkmark$ & & & & $\checkmark$ & $\checkmark$ & $\checkmark$ & & $\checkmark$ & $\checkmark$ \\
\hline & Commercial paper & $\checkmark$ & $\checkmark$ & $\checkmark$ & $\checkmark$ & $\checkmark$ & & & & & & & $\checkmark$ & & & \\
\hline & Corporate bonds & $\checkmark$ & $\checkmark$ & $\checkmark$ & $\checkmark$ & $\checkmark$ & & & & & & & $\checkmark$ & & $\checkmark$ & \\
\hline & Other private securities ${ }^{\mathrm{b}}$ & & $\checkmark$ & $\checkmark$ & & $\checkmark$ & & & & & & & & & & \\
\hline \multirow[t]{2}{*}{ FX swap/intervention } & USD swap line & & $\checkmark$ & $\checkmark$ & $\checkmark$ & $\checkmark$ & $\checkmark$ & $\checkmark$ & $\checkmark$ & & & & $\checkmark$ & $\checkmark$ & & \\
\hline & FX intervention & & & & & & & $\checkmark$ & $\checkmark$ & & $\checkmark$ & $\checkmark$ & $\checkmark$ & $\checkmark$ & & \\
\hline \multirow[t]{4}{*}{ Prudential rules and regulations } & Capital requirements & $\checkmark$ & $\checkmark$ & $\checkmark$ & $\checkmark$ & $\checkmark$ & $\checkmark$ & $\checkmark$ & $\checkmark$ & $\checkmark$ & $\checkmark$ & $\checkmark$ & $\checkmark$ & $\checkmark$ & & $\checkmark$ \\
\hline & Liquidity requirements & $\checkmark$ & $\checkmark$ & $\checkmark$ & $\checkmark$ & $\checkmark$ & $\checkmark$ & $\checkmark$ & $\checkmark$ & $\checkmark$ & $\checkmark$ & $\checkmark$ & $\checkmark$ & $\checkmark$ & $\checkmark$ & $\checkmark$ \\
\hline & Payout restrictions & & $\checkmark$ & & $\checkmark$ & $\checkmark$ & $\checkmark$ & $\checkmark$ & $\checkmark$ & & $\checkmark$ & $\checkmark$ & $\checkmark$ & $\checkmark$ & $\checkmark$ & $\checkmark$ \\
\hline & Market functioning $^{\mathrm{c}}$ & $\checkmark$ & $\checkmark$ & $\checkmark$ & $\checkmark$ & $\checkmark$ & $\checkmark$ & $\checkmark$ & $\checkmark$ & $\checkmark$ & $\checkmark$ & $\checkmark$ & $\checkmark$ & $\checkmark$ & $\checkmark$ & $\checkmark$ \\
\hline
\end{tabular}

${ }^{a}$ For example, repo and reverse repo operations, standing facilities, modified discount window and lower reserve requirement ratio

${ }^{\mathrm{b}}$ For example, asset- and mortgage-backed securities, covered bonds and exchange-traded funds

${ }^{c}$ For example, short-selling bans and circuit breakers 


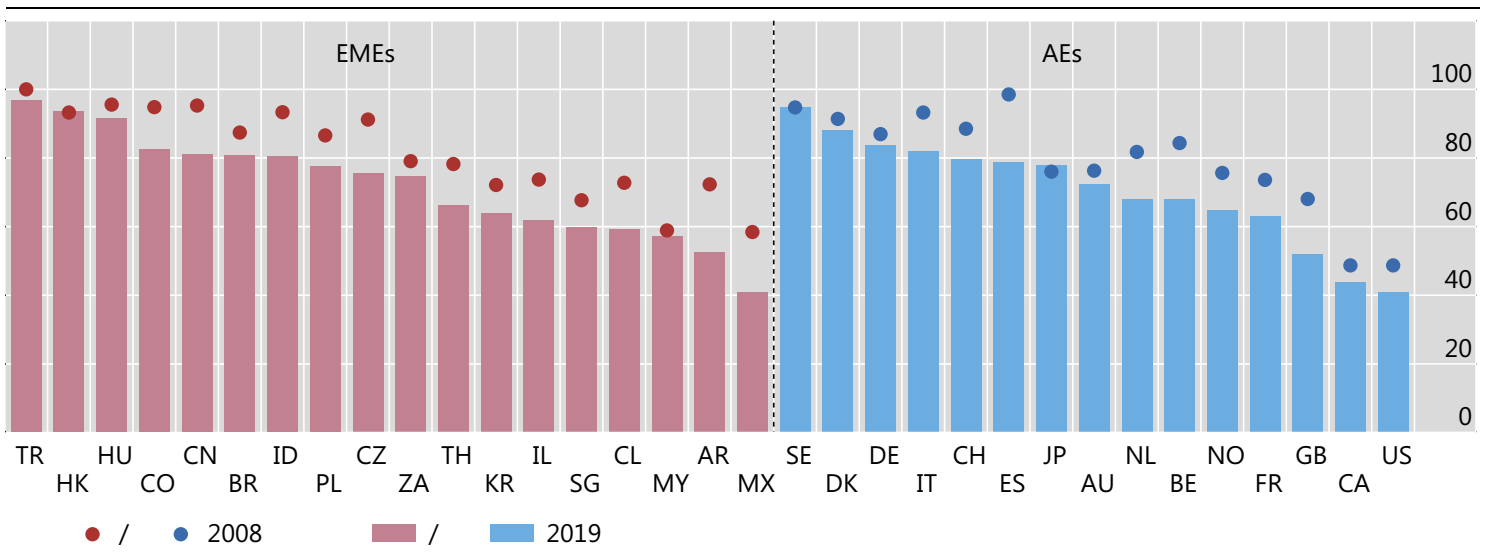

1 Bank loans to non-financial corporations (NFCs) as a share of the sum of bank loans to NFCs and debt securities issued by NFCs. If bank loans are not available, bank credit to NFCs (BR, CO and MY) or bank claims on NFCs (CN) are used. Debt securities issued by NFCs measured as total debt securities; if not available, sum of domestic and international debt securities.

Sources: Datastream; Dealogic; Euroclear; Thomson Reuters; Xtrakter Ltd; national data; BIS calculations.

Fig. 2 Share of bank loans in firms' financing has fallen ${ }^{1}$ (in percent)

effort to stabilise markets. Indeed, for the first time, central banks in emerging market economies (EMEs) have done the same, by intervening in their now better developed domestic currency bond markets, where foreign investor participation has greatly increased (Arslan et al. 2020). This is testimony to EMEs' much stronger and more credible macroeconomic frameworks, which have also allowed central banks to cut, rather than raise, policy rates.

In another respect, monetary policy has broken new ground. Central banks have gone one step further relative to the past, seeking to cover "the last mile" to reach businesses directly, including small and medium-sized enterprises. They have done this through backstops for bank funding. For example, think of the Fed's Main Street Lending Program and its direct purchases of corporate securities. In the process, central banks have gone down the credit scale more than ever before, including taking on risk below investment grade (or the equivalent when companies are unrated).
Prudential policy has taken an unprecedented direction (Borio 2020; Borio and Restoy 2020). Rather than encouraging banks to shore up their balance sheets and retrench, it has actually encouraged them to partly draw down the capital buffers accumulated since the GFC in order to keep credit flowing. By "capital buffer", I mean the amount of capital above regulatory minima. To that effect, prudential authorities around the world have used the available flexibility to: ease both capital and liquidity requirements; impose blanket distribution restrictions, such as on dividends; and ease both the classification of exposures, such as non-performing loans, and the regulatory treatment of accounting losses-specifically, the new expected credit loss provisioning standard (Fig. 3).

This fundamental change in approach reflects three factors. The first is the sense that everyone had to play their part to tackle the emergency. The second is the post-GFC change in perspective from a purely microprudential (MiP) approach-focused on the safety of individual banks
Fig. 3 Countries taking easing prudential measures (in per cent)

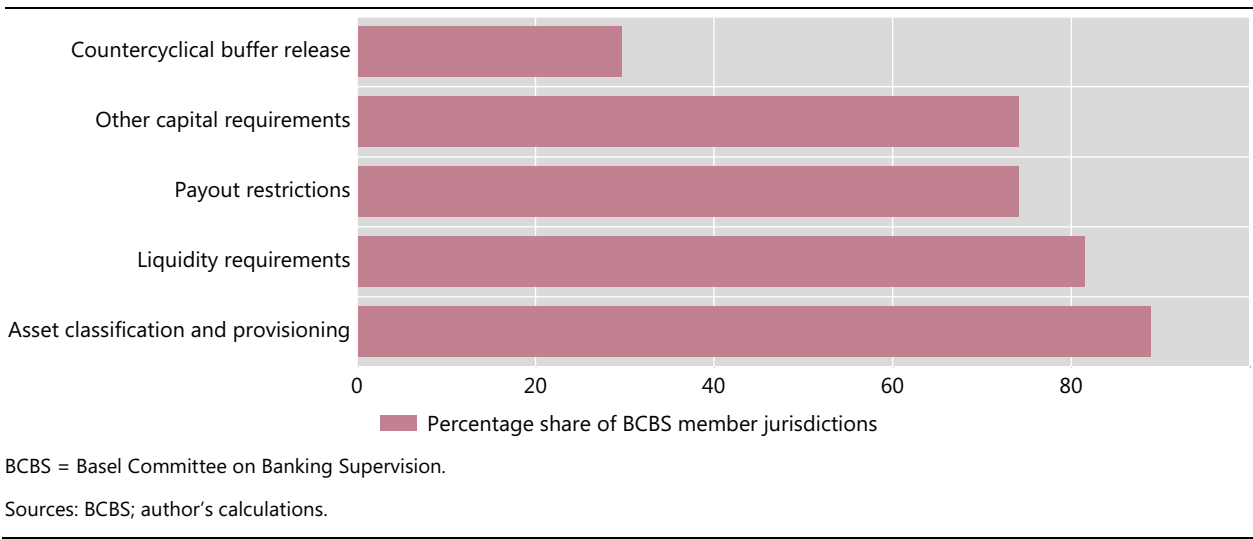



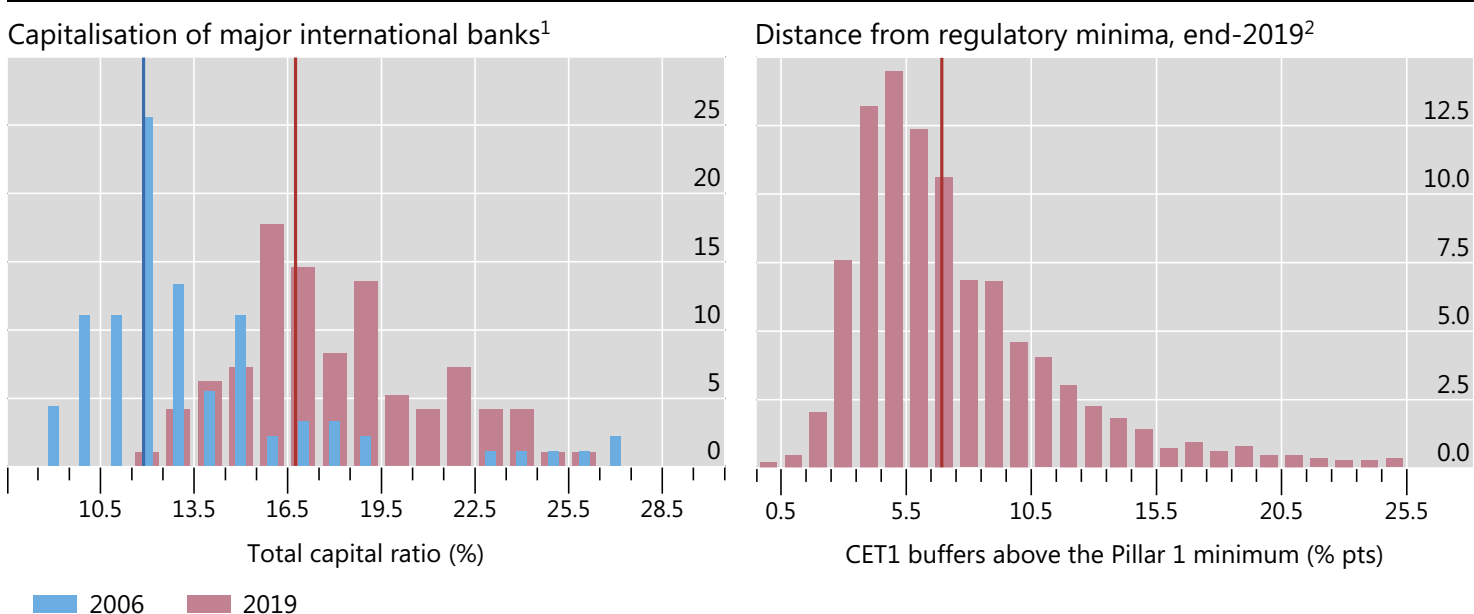

The vertical lines indicate the median for the respective year.

1 Based on a balanced sample of 135 large banks. The increase in capital ratios is likely to be higher than portrayed due to more stringent rules on regulatory capital and risk-weighted assets introduced after the GFC. 2 Difference between the Common Equity Tier 1 (CET1) ratio and the sum of the following regulatory requirements: minimum Basel III CET1 ratio ( $4.5 \%)$, capital conservation buffer ( $2.5 \%$, assuming full implementation), the bank-specific capital surcharge on systemically important banks and the country-specific countercyclical capital buffer (up to $2 \%$ ) at end-2019. Based on a global sample of 3,616 banks.

Sources: Aldasoro et al (2020); Lewrick et al (2020); FitchConnect; BIS calculations.

Fig. 4 Banks entered the crisis in a strong position (in percent)

considered in isolation - to a more macroprudential (MaP) approach, which considers them as part of a system (Borio 2018). Hence the notion of the "fallacy of composition": it may be rational and indeed compelling for each institution to retrench and cut lending as the outlook deteriorates. But, if all do so collectively, they may actually end up worse off because of the spillbacks from the real economy. This is an instance of the excessive procyclicality of the financial system. Finally, the unique response reflects the fact that the banking system was much better capitalised going into the crisis, largely thanks to the post-GFC financial reforms (Fig. 4). As a result, policymakers could look upon banks as part of the solution, rather than as part of the problem.

In its own way, fiscal policy, too, has broken new ground. Huge size aside (Fig. 5), it has responded with a speed that is in all likelihood unprecedented. And it has adjusted the

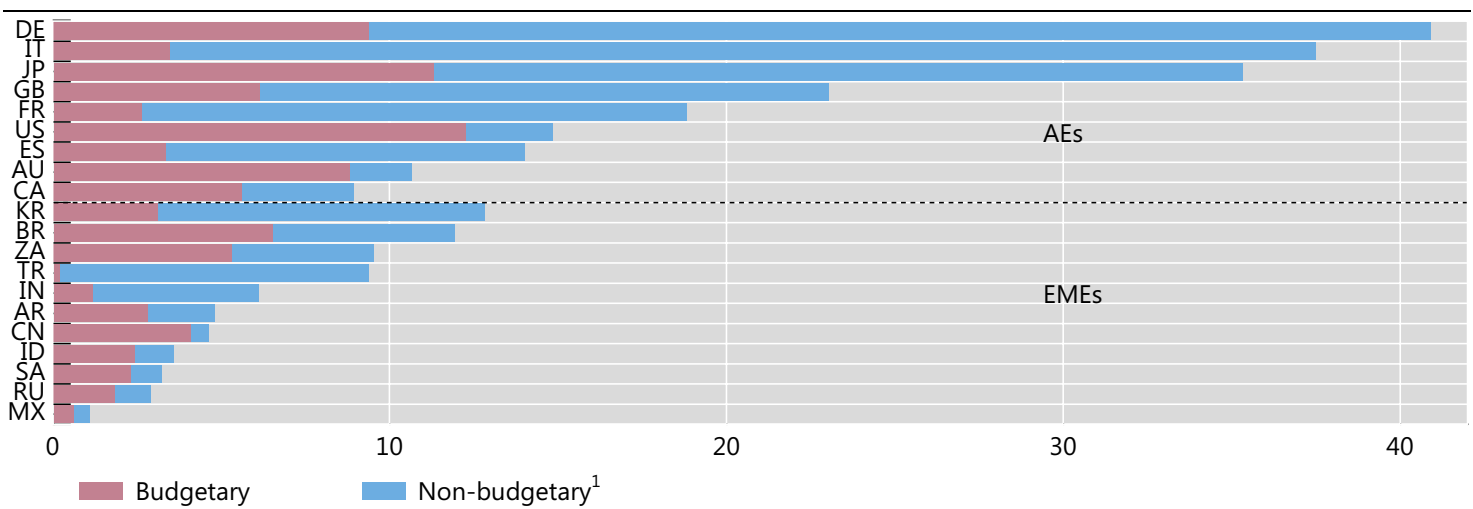

Estimates focus on government discretionary measures that supplement existing automatic stabilisers, which differ across countries in their breadth and scope.

1 Equity injections, asset purchases, loans and debt assumptions, including through extra-budgetary funds. Guarantees on loans and other contingent liabilities such as loans channelled through public financial agencies.

Sources: IMF, Fiscal Monitor, IMF, World Economic Outlook; national data; BIS calculations.

Fig. 5 Prompt and forceful fiscal response (as a percentage of GDP) 


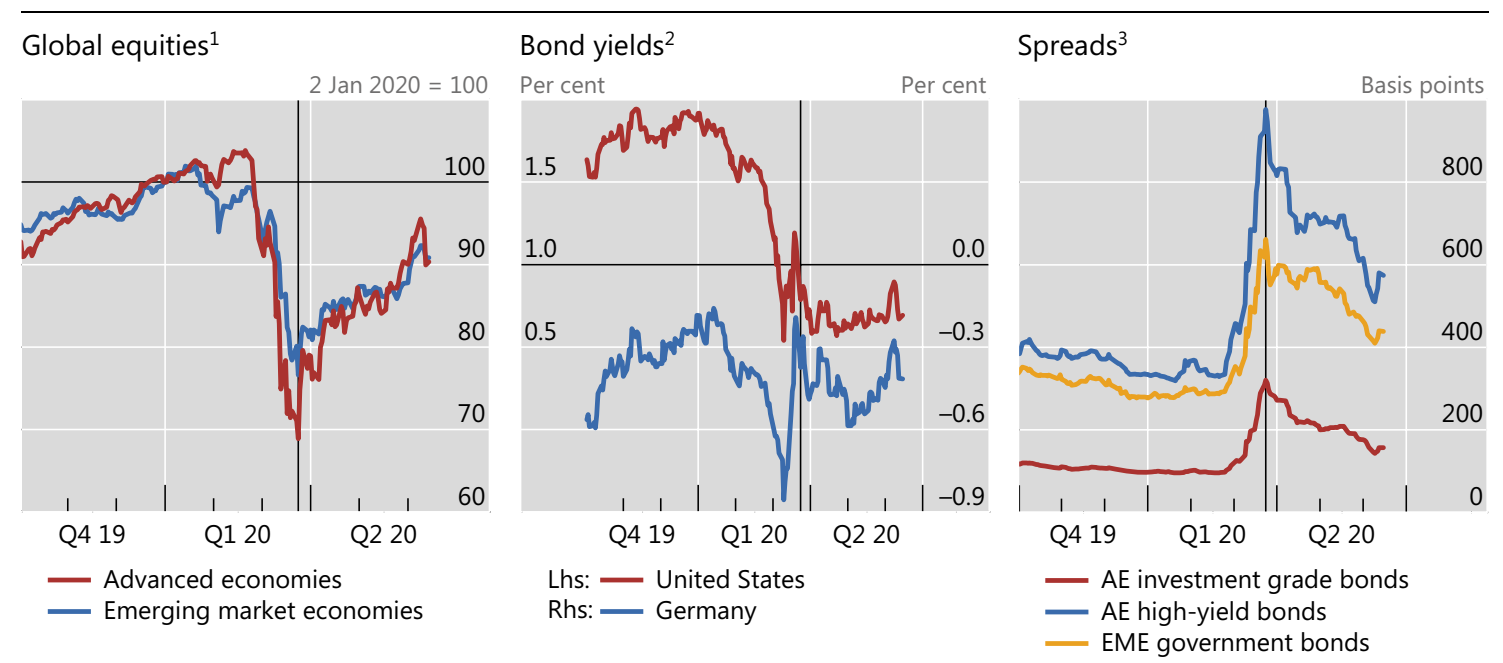

The vertical lines indicate 23 March 2020 (the Federal Reserve announces the Primary Market Corporate Credit Facility (PMCCF) and the Secondary Market Corporate Credit Facility (SMCCF)).

1 Based on GDP-weighted averages across countries. Advanced economies (AEs) = AU, CA, CH, DK, EA, GB, JP, NO, NZ, SE and US. Emerging market economies (EMEs) $=\mathrm{BR}, \mathrm{CL}, \mathrm{CN}, \mathrm{CO}, \mathrm{CZ}, \mathrm{HU}, \mathrm{HK}, \mathrm{IN}, \mathrm{ID}, \mathrm{KR}, \mathrm{MX}, \mathrm{MY}, \mathrm{PE}, \mathrm{PH}, \mathrm{PL}, \mathrm{RU}, \mathrm{SG}, \mathrm{TH}$, TR and ZA. 2 Ten-year government bond yields. ${ }^{3}$ Corporate bonds for AEs and government bonds for EMEs. For AEs, simple average of US and Europe indices.

Sources: Bloomberg; BoAML ICE indices; JPMorgan Chase; national data; BIS calculations.

Fig. 6 Policies have stabilised markets

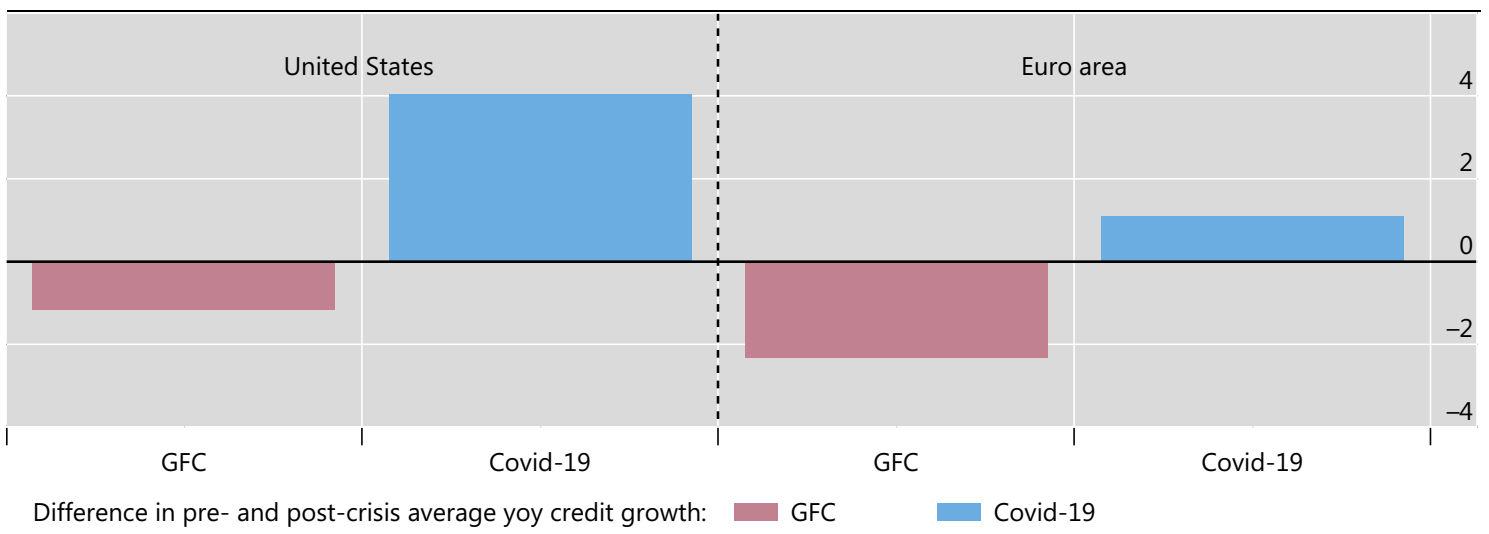

Pre-GFC = August 2007 to August 2008; pre-Covid-19 = January 2019 to January 2020; post-GFC = October to December 2008; post-Covid-19 = March to May 2020 for the United States and March to April 2020 for the euro area.

Sources: National data; BIS calculations.

Fig. 7 Credit expanded considerably more during this crisis than during the GFC (in percentage points)

response to the nature of the shock. Hence the heavy reliance on furlough schemes designed to keep employees attached to their firms, and on guarantees extended either to borrowers, thereby providing banks with essential incentives to keep lending, or to the central bank, thereby leveraging its firing power.

So far, the concerted policy response seems to have worked. Financial markets have stabilised-if anything, "too much", in the sense that risky asset prices appear to have run ahead of a realistic assessment of the economic outlook (Fig. 6). Credit has kept flowing: bank credit has increased, while it had contracted during the GFC (Fig. 7). In part, this reflects the fact that, as firms drew on their credit lines, banks did not cut other forms of lending, at least to the same extent, and the economy has withstood the shock. Granted, the drop in activity has been dramatic. But activity has begun to rebound since the easing of 


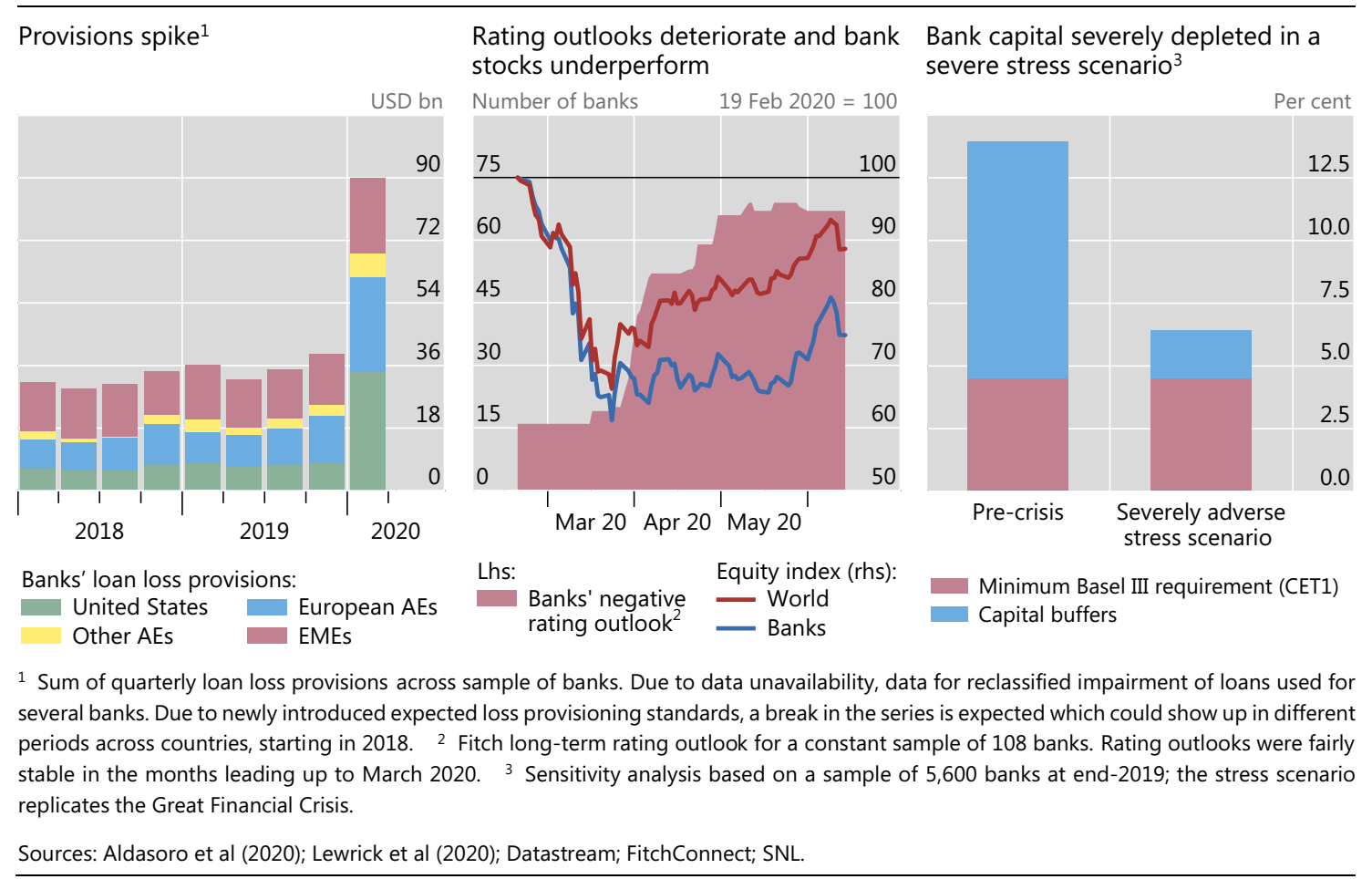

Fig. 8 Banks are under pressure and buffers are limited if the crisis persists

containment measures (Fig. 1), and the drop would surely have been much bigger without such a vigorous policy response.

Still, near-term and longer-term challenges remain, and they crucially depend on the uncertain evolution of the pandemic.

\section{Near-term challenges}

The crisis raises two specific near-term challenges: how to deal with the interim increase in private and public sector debt, and with possible future long-lasting changes in demand patterns, respectively.

The available options and difficulties involved depend on how long the crisis lasts, which in turn depends on whether we will see more infection waves and on how the health authorities will respond. The surrounding uncertainty hugely complicates policy in real time. If the containment measures are progressively and permanently lifted, it is reasonable to expect that the economy will return to operate more normally in a generally smooth way-just as a cushion regains its original shape once it is no longer held down. To be sure, higher debt and changes in demand patterns will slow down progress, but the problems are likely to remain manageable. By contrast, if the health emergency lasts much longer, then the economic problems will be more serious.
Consider the policy implications for the choices to be made as economies transition from the illiquidity to the insolvency phase and the room for manoeuvre remains limited and shrinks further.

In the insolvency phase, it is fiscal authorities that will have to do the heavy lifting. They will need to guide and work alongside market mechanisms to address companies' debt overhang and structural adjustments. In this phase, there is little monetary policy can do: monetary policy can lend, but cannot spend (i.e. transfer real resources outright). The tricky task is to distinguish viable from non-viable firms despite the huge uncertainties involved. The mechanisms are well known. They range from formal bankruptcy proceedings, which could become overstretched, to more informal and expedited out-of-court arrangements. Here the government can play a variety of roles, from providing a general framework to taking equity stakes in companies, thereby socialising both opportunities and losses. Experience indicates that addressing the debt overhang at source is key to setting the basis for a lasting and strong recovery. The business sectors' balance sheets were overstretched to start with, not least as a result of low-for-long interest rates. This will complicate policy by exacerbating the debt overhang and by making it harder to distinguish viable from non-viable firms. The losses, in turn, could put banks under stress, as signalled 
Massive widening fiscal deficits expected for 2020

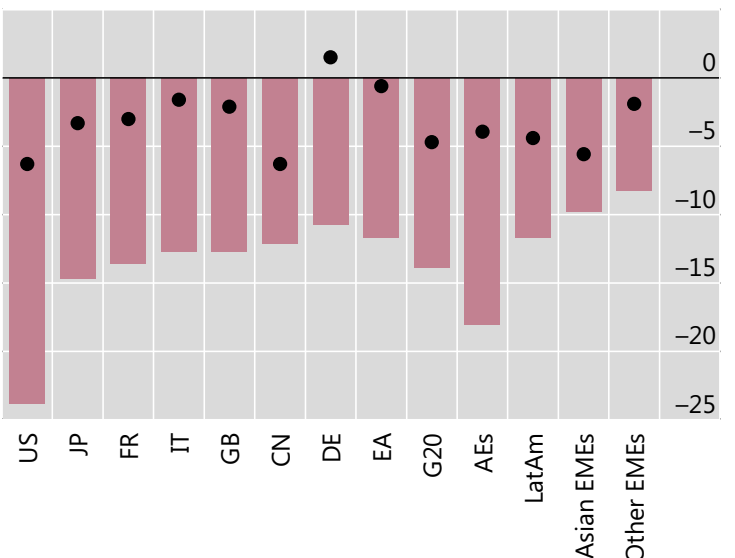

- 2019
Public debts likely to undergo steepest increase since GFC

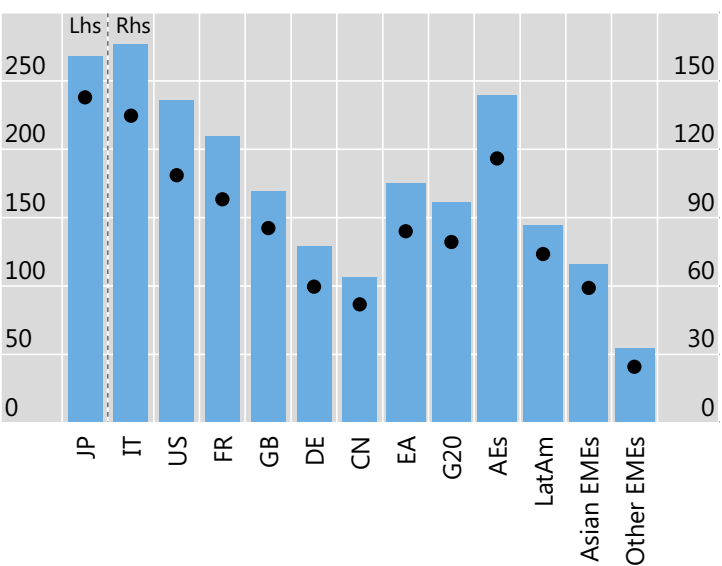

- 2019

For regions, weighted averages based on GDP and PPP exchange rates. $A E S=A U, C A, D E, E S, F R, G B, I T, J P$ and $U S ;$ LatAm $=B R$ and $M X ; A$ sian EMEs = ID, IN and KR; Other EMEs = RU, SA, TR and ZA.

Sources: IMF, World Economic Outlook, June 2020; BIS calculations.

Fig. 9 Soaring public debt (as a percentage of GDP)

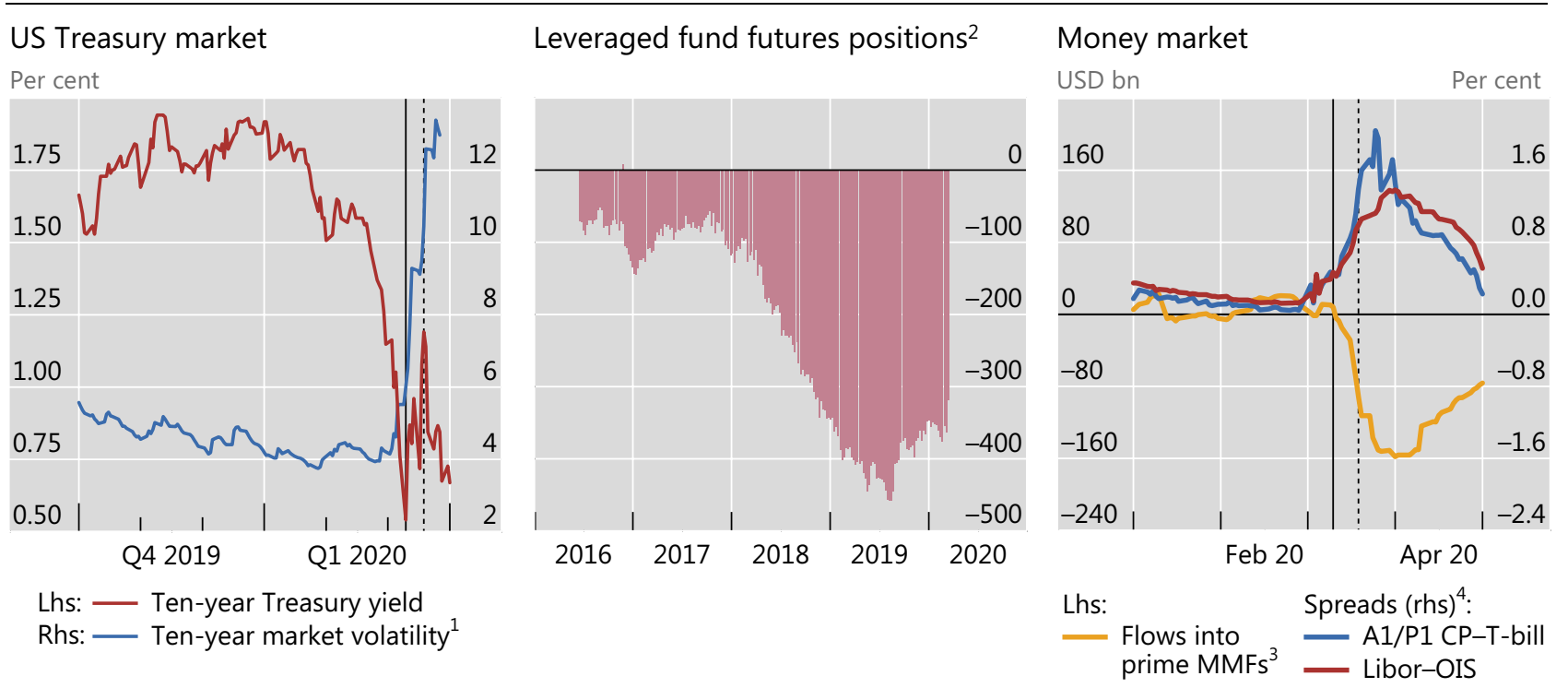

The solid vertical lines in the left-hand and right-hand panels indicate 9 March 2020 (the date of the spike in the Treasury yield). The dashed lines indicate 18 March 2020 (the establishment of the Federal Reserve's Money Market Mutual Fund Liquidity Facility, MMLF).

${ }^{1}$ Exponentially weighted moving average volatility over a one-year window (decay factor $=0.96$ ). ${ }^{2}$ Net US Treasury futures positions. ${ }^{3}$ Cumulative changes in assets under management by US money market funds (MMFs) since December $2019 .{ }^{4}$ Three-month funding spreads. During the GFC, Libor-OIS reached 366 basis points on 10 October 2008.

Sources: Schrimpf et al (2020); Egemen et al (2020a); Bloomberg; CFTC; Crane Data; BIS calculations.

Fig. 10 Turmoil in US markets

by accounting measures, ratings and market indicators as well as by simple sensitivity analysis (Fig. 8).
Where is the bias likely to be? Doing too much and keeping unviable firms in operation? Or doing too little and liquidating viable ones? Where the fiscal room for policy 


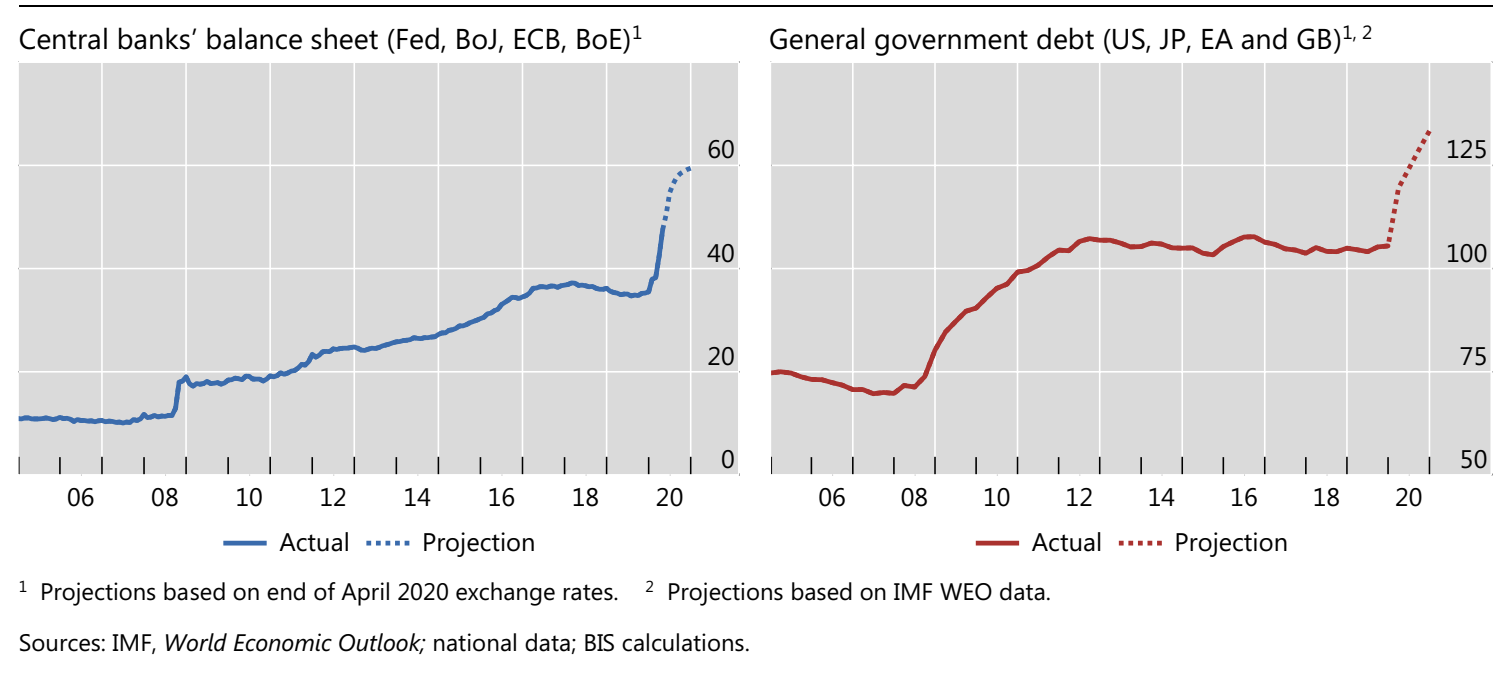

Fig. 11 Monetary and fiscal interactions will be prominent going forward (as a percentage of GDP)

manoeuvre is very small, the main risk probably is that the authorities will do too little; where it is ample, that they will do too much, possibly even testing the boundaries of sustainability. The political economy works very much in that direction. The costs of doing too little are immediate and highly visible, in the form of bankruptcies and job losses; those of doing too much are longer-term and largely invisible, in the form of efficiency gains and higher long-term growth. Keeping unviable firms alive-the so-called zombies-can have major costs, as it generates excess capacity and deprives more competitive firms of badly needed oxygen. The risk is all the greater at unusually low interest rates (Banerjee and Hofmann 2018). As a result, monetary policy, too, will find it difficult to disengage: it would be seen as pulling the plug when fiscal authorities are striving to keep it in place.

All this puts the spotlight on the need to ensure that public finances remain sustainable. The sovereign acts as a critical backstop for the private sector, but no one can act as backstop for the sovereign other than the international community. EMEs and those advanced economies without an independent monetary policy face more serious challenges in this respect.

The general issue of the limited and shrinking policy room for manoeuvre is even trickier. Policymakers have gone "all in", partly in the expectation that the pandemic will be short-lived. Fiscal deficits and government debt have surged; central banks' policy rates have fallen further and their balance sheets have soared (Fig. 9). If the pandemic lasts longer than expected, the much narrower policy space will raise veritable dilemmas. After all, policy buffers are, by construction, limited. Hence the need for a measured and targeted approach going forward, providing the necessary flexibility to respond as the uncertainty dissipates.

\section{Longer-term challenges}

Looking further ahead, three challenges loom large. They pertain, respectively, to the regulatory framework, to monetary-fiscal policy interactions and to policy buffers generally.

First challenge: If policymakers have so far looked upon banks as part of the solution rather than of the problem, the same is not true for other parts of the financial system. Market-based finance stands out in this respect. This segment was quite prominent in the disruptions that caused turmoil in financial markets and threatened to freeze funding. Think, in particular, of the extraordinary disruptions to the US Treasury market, which highlighted the nexus between hedge fund operations and other investment vehicles, most notably money market mutual funds (Schrimpf et al. 2020; Eren et al. 2020a; and Fig. 10). The shock waves spread as far as offshore US funding markets and were one reason why the Federal Reserve reactivated FX swap lines with other central banks (Eren et al. 2020b; Avdjiev et al. 2020) and introduced a special repo facility for foreign central banks more generally (FIMA). Twice in the space of a little over one decade, central banks have had to intervene massively in order to stabilise markets because of disruptions to marketbased finance. This is not a satisfactory state of affairs: it is a pressure point in the financial system and it risks generating moral hazard. Further regulatory reflections and action are called for (Borio et al. 2020). 


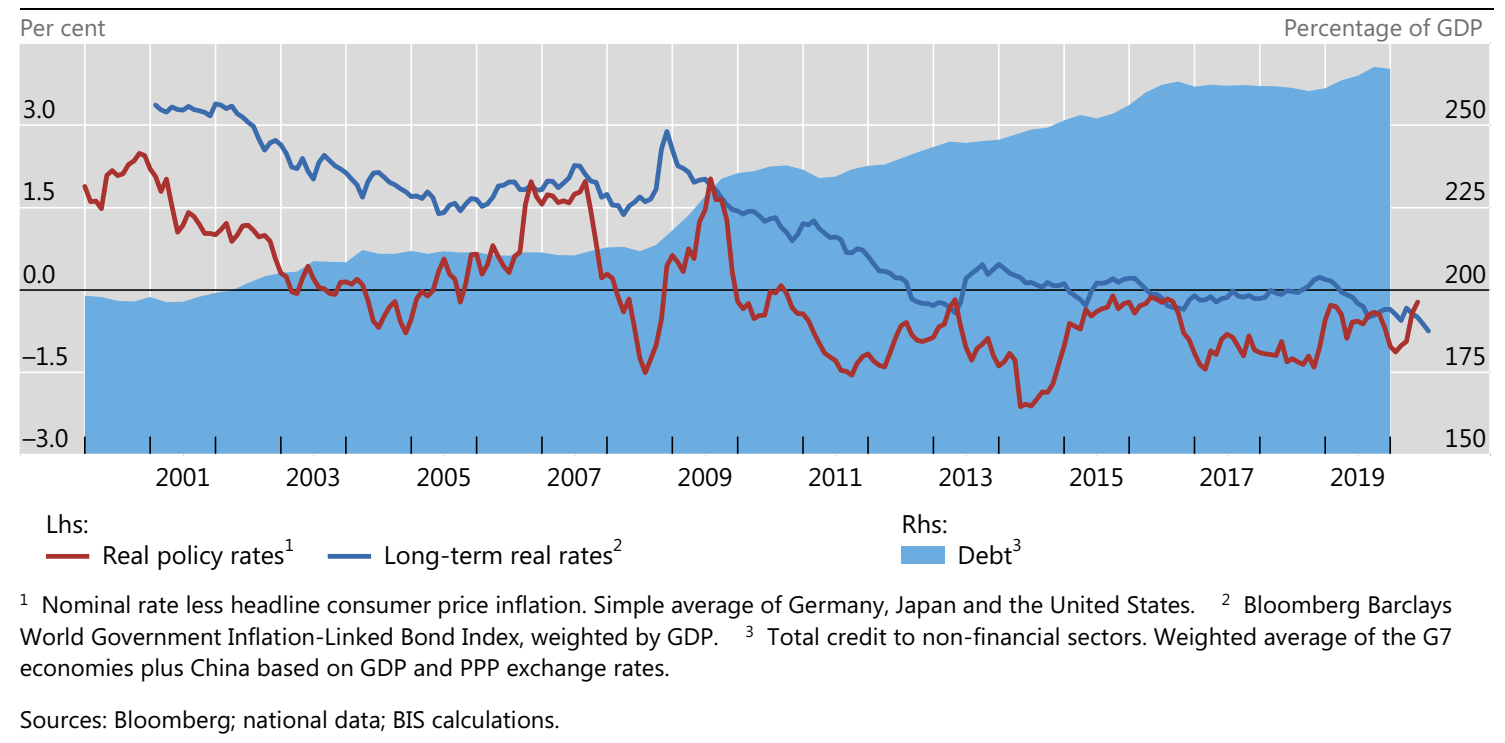

Fig. 12 Into a debt trap?

Second challenge: Monetary and fiscal policies have rightly been coordinated closely during the crisis. But as conditions normalise, it will be essential to again sharpen the demarcation lines between the two; extraordinary measures are only for extraordinary times. So far, the objectives of central banks and governments have coincided, but they are likely to diverge once central banks need to tighten policy, either simply to regain room for manoeuvre or to fight rising inflation. Admittedly, in the near term, disinflationary pressures will probably prevail. But this may well change at some point, especially if a regime change takes place, such as a reversal of globalisation. Such a reversal would restore at least some of the pricing power that both labour and firms have lost over the years, thereby boosting second-round effects (Borio 2017a). Governments may well wish to keep their borrowing costs low, thereby putting pressure on central banks. At that point, it is crucial that central banks be able to stick to their mandates. Central bank independence will be critical to preserve credibility (Borio 2019). Preserving credibility is of the essence. It is precisely what has allowed central banks to take such extraordinary actions during this crisis.

This also speaks to the confusing debate regarding monetary financing (Borio et al. 2016). The simultaneous increase in public debt and central bank balance sheets, mainly as a result of purchases of government securities, has added fuel to the debate (Fig. 11). There is a technical aspect involved: purchasing government securities is part and parcel of standard monetary policy implementation. The meaningful economic dividing line between monetary and non-monetary financing has to do with who is in control and the reasons for the actions taken. As long as central banks are in control of what they do, and what they do is in line with their mandates, the issue of monetary financing is not particularly relevant: it is more rhetoric than substance.

Third challenge: As soon as conditions allow, rebuilding policy buffers should be a priority. This is true of prudential, monetary and fiscal buffers. This episode has reminded us once more that precautionary buffers, far from being a luxury, are absolutely essential, regardless of how unlikely adverse outcomes may seem. Indeed, rebuilding policy buffers is probably the challenge of the decade ahead. Monetary policy used up substantial policy space post-GFC. Fiscal policy, even as debt-to-GDP ratios rose to cushion the blow, was rightly invoked to take up the relay in the next downturn. Now, it has fully played its part, even as monetary policy, unfortunately, could not take a breather. But fiscal policy has done so at the cost of much higher debt and risks to sustainability in some countries. The pre-Covid crisis experience has shown just how difficult it is to normalise monetary policy and to consolidate fiscal positions; only prudential policy succeeded in replenishing buffers post-GFC.

Failure to regain room for policy manoeuvre would raise serious risks for macroeconomic, price and financial stability. Prudential policy, while essential, cannot alone carry the burden of securing financial stability. Regaining policy space will require a clear recognition that neither monetary policy nor fiscal policy can, on their own, generate sustainable growth alongside financial stability. Only a judicious balance of monetary, fiscal and prudential policies, underpinned by badly needed structural reforms, can do so. Most importantly, it will require determination, patience and a firm focus on the long term: after all, however, distant it may appear, the future eventually becomes today. 


\section{Conclusion}

It is probably too early to tell, but future economic historians may well consider the Covid-19 pandemic a defining moment of the twenty-first century. When, just over a decade ago, the GFC hit the global economy, it was rightly considered such a moment. The pandemic's legacy could be even deeper and longer-lasting.

This dangerously unique crisis may have accelerated a trend that was well under way before it struck-higher private and public debt, lower interest rates and shrinking fiscal and monetary room for policy manoeuvre. As I have argued elsewhere, the trend gave rise to the risk of a kind of "debt trap", whereby it would be increasingly difficult to raise interest rates without causing economic damage (Borio 2017b; and Fig. 12). Ultimately, that same trend could even lead to a change in policy regime-a political and economic retreat behind national borders, a greater role for the state in the economy and, possibly, a re-emergence of inflation as a serious policy challenge. But the future is not preordained. It is up to policy to chart the right course.

\section{References}

Aldasoro, Iñaki, Ingo Fender, Bryan Hardy, and Nikola Tarashev. 2020. Effects of Covid-19 on the banking sector: the market's assessment, BIS Bulletin no. 12, May 7. https://www.bis.org/publ/bisbu 1112.htm. Accessed 24 July 2020.

Arslan, Yavuz, Mathias Drehmann, and Boris Hofmann. 2020. Central bank bond purchases in emerging market economies, BIS Bulletin no. 20 , June 2. https://www.bis.org/publ/bisbull20.htm. Accessed 24 July 2020.

Avdjiev, Stefan, Egemen Eren, and Patrick McGuire. 2020. Dollar funding costs during the Covid-19 crisis through the lens of the FX swap market, BIS Bulletin no. 1, 1 April 1. https://www.bis. org/publ/bisbullo1.htm. Accessed 24 July 2020.

Banerjee, Ryan Niladri, and Boris Hofmann. 2018. The rise of zombie firms: causes and consequences, BIS Quarterly Review September: 67-78. https://www.bis.org/publ/qtrpdf/r_qt1809g.htm. Accessed 24 July 2020.

Bank for International Settlements. 2020. Annual Economic Report 2019/20.

Borio, Claudio. 2017a. Through the looking glass, OMFIF City Lecture, London, September 22. https://www.bis.org/speeches/sp170 922.pdf. Accessed 24 July 2020.

Borio, Claudio. 2017b. Secular stagnation or financial cycle drag? Business Economics 52 (2): 87-98.

Borio, Claudio. 2018. Macroprudential frameworks: experience, prospects and a way forward, speech on the occasion of the Bank's Annual General Meeting, Bank for International Settlements, June
24. https://www.bis.org/speeches/sp180624a.htm. Accessed 24 July 2020

Borio, Claudio. 2019. Central banking in challenging times, SUERF Annual Lecture delivered at the Conference on Populism, economic policies and central banking, SUERF/BAFFI CAREFIN Centre Conference, Milan, November 8. https://www.bis.org/ speeches/sp191108a.htm. Accessed 24 July 2020.

Borio, Claudio. 2020. The prudential response to the Covid-19 crisis, speech on the occasion of the presentation of the Bank's Annual General Meeting, Bank for International Settlements 30 June 30. https://www.bis.org/speeches/sp200630a.htm. Accessed 24 July 2020.

Borio, Claudio, Piti Disyatat, and Anna Zabai. 2016. Helicopter money: the illusion of a free lunch, VoxEU, May 24. https://www. bis.org/speeches/sp200630a.htm. Accessed 24 July 2020.

Borio, Claudio, Marc Farag, and Nikola Tarashev. 2020. Post-crisis international financial regulatory reforms: a primer, BIS Working Papers no. 859, April. https://papers.ssrn.com/sol3/paper s.cfm?abstract_id=3584707. Accessed 24 July 2020.

Borio, Claudio, and Fernando Restoy. 2020. Reflections on regulatory responses to the Covid-19 pandemic, FSI Briefs, no. 1, April 15. https://www.bis.org/fsi/fsibriefs1.htm. Accessed 24 July 2020.

Eren, Egemen, Andreas Schrimpf, and Vladyslav Sushko. 2020a. US dollar funding markets during the Covid-19 crisis - the money market fund turmoil, BIS Bulletin no. 14,12 May 12. https://www. bis.org/publ/bisbull14.htm. Accessed 24 July 2020.

Eren, Egemen, Andreas Schrimpf, and Vladyslav Sushko. 2020b. US dollar funding markets during the Covid-19 crisis-the international dimension, BIS Bulletin, no 15, May 12. https://www.bis. org/publ/bisbull15.htm. Accessed 24 July 2020.

Lewrick, Ulf, Christian Schmieder, Jhuvesh Sobrun, and Előd Takáts. 2020. Releasing bank buffers to cushion the crisis-A quantitative assessment, BIS Bulletin no 11, May 5. https://www.bis.org/publ/ bisbull11.htm. Accessed 24 July 2020.

Schrimpf, Andreas, Hyun Song Shin, and Vladyslav Sushko. 2020. Leverage and margin spirals in fixed income markets during the Covid-19 crisis, BIS Bulletin no. 2, April 2. https://www.bis.org/ publ/bisbull02.htm. Assessed 24 July 2020.

Publisher's Note Springer Nature remains neutral with regard to jurisdictional claims in published maps and institutional affiliations.

Claudio Borio was appointed Head of the Monetary and Economic Department (MED) of the Bank for International Settlements on November 18, 2013. At the BIS since 1987, Mr Borio has held various positions in the MED, including Deputy Head and Director of Research and Statistics, as well as Head of Secretariat for the Committee on the Global Financial System and the Gold and Foreign Exchange Committee (now the Markets Committee). From 1985 to 1987, he was an economist at the OECD, working in the country studies branch of the Economics and Statistics Department. Prior to that, he was Lecturer and Research Fellow at Brasenose College, Oxford University. He holds a DPhil and an MPhil in Economics and a BA in Politics, Philosophy and Economics from the same university. Claudio is author of numerous publications in the fields of monetary policy, banking, finance and issues related to financial stability. 